\title{
TOPOGRAPHICAL ORGANIZATION OF INFERIOR OLIVE CELLS PROJECTING TO TRANSLATION AND ROTATION ZONES IN THE VESTIBULOCEREBELLUM OF PIGEONS
}

\author{
K. L. LAU, R. G. GLOVER, B. LINKENHOKER and D. R. W. WY LIE* \\ D epartment of Psychology, U niversity of A lberta, Edmonton, A lberta, Canada, T6G 2E 9
}

\begin{abstract}
A bstract--Previous electrophysiological studies in pigeons have shown that the vestibulocerebellum can be divided into two parasagittal zones based on responses to optic flow stimuli. The medial zone responds best to optic flow resulting from self-translation, whereas the lateral zone responds best to optic flow resulting from self-rotation. This information arrives from the retina via a projection from the accessory optic system to the medial column of the inferior olive. In this study we investigated inferior olive projections to translational and rotational zones of the vestibulocerebellum using the retrograde tracer cholera toxin subunit B. Extracellular recordings of Purkinje cell activity (complex spikes) in response to large-field visual stimuli were used to identify the injection sites. W e found a distinct segregation of inferior olive cells projecting to translational and rotational zones of the vestibulocerebellum. Translation zone injections resulted in retrogradely labeled cells in the ventrolateral area of the medial column, whereas rotation zone injections resulted in retrogradely labeled cells in the dorsomedial region of the medial column.

M otion of any object through space, including self-motion of organisms, can be described with reference to translation and rotation in three-dimensional space. Our results show that, in pigeons, the brainstem visual systems responsible for detecting optic flow are segregated into channels responsible for the analysis of translational and rotational optic flow in the inferior olive, which is only two synapses from the retina. (C) 1998 IBR O. Published by Elsevier Science L td.
\end{abstract}

Key words: optokinetic, optic flow, accessory optic system, visual-vestibular integration, self-motion, cholera toxin subunit B.

The motion of any object through space can be described with respect to its translation between two points in space, and its rotation relative to some frame of reference. Any organism moving through space has a nervous system designed to provide information about self-motion. The vestibular apparatus contains the semicircular canals and the otolith organs, which are sensitive to head rotation and translation, respectively. ${ }^{27}$ Numerous other sensory systems contribute to the analysis of self-motion, including the visual system. That vision can serve as a proprioceptive sense was emphasized by Gibson,, 910 who noted that, because the environment contains numerous stationary visual stimuli, self-motion induces "flow fields" or "optic flow" across the entire retina. Self-rotation results in a rotational flow field that is opposite to the direction of one's head rotation. The flow field resulting from self-translation consists of a "focus of expansion" (fe), which is a

*To whom correspondence should be addressed.

A bbreviations: BDA, biotinylated dextran amine; CS complex spike; CTB, cholera toxin subunit $B$; DAB, diaminobenzidine; $\mathrm{dl}$, dorsal lamella; fe, focus of expansion; IO, inferior olive; $\mathrm{mc}$, medial column; $\mathrm{PB}$, phosphate buffer; PBS, phosphate-buffered saline; VA, vertical axis; $\mathrm{VbC}$, vestibulocerebellum; vl, ventral lamella; XII, cranial nerve XII (hypoglossal nerve). point in the direction of translation from which all visual images radiate outward. A long the axis of translation, but in the direction opposite to the translation vector, is a "focus of contraction", a point to which all visual images converge.

The accessory optic system is a component of the visual system dedicated to the analysis of optic flow. ${ }^{12,19,20} \mathrm{~N}$ uclei of the accessory optic system project to areas of the inferior olive (IO) that provide climbing fiber input to the contralateral vestibulocerebellum $(\mathrm{VbC})^{1,6-8,20,33}$ In pigeons, the $\mathrm{VbC}$ consists of folium $X$ (nodulus), the ventral lamella of folium IXc,d (ventral uvula) and the auricle (flocculus), which is the lateral extension of these folia. ${ }^{18}$ Previous electrophysiological studies of the pigeon $\mathrm{VbC}$ have shown that complex-spike (CS) activity of Purkinje cells (which reflects climbing fiber activity) responds best to specific patterns of optic flow resulting from either self-translation or self-rotation. ${ }^{29-32}$ Translation- and rotationsensitive neurons are organized into two parasagittal zones. Cells in the medial VbC (nodulus and ventral uvula) and lateral $\mathrm{VbC}$ (flocculus) respond best to translational and rotational optic flow, respectively. The boundary between the two zones was located approximately $1.8-2 \mathrm{~mm}$ from the midline. 
Table 1. A summary of the locations of injection sites and retrogradely labeled cells in the inferior olive

\begin{tabular}{|c|c|c|c|c|c|c|c|}
\hline & \multirow[b]{2}{*}{$\begin{array}{c}\text { Preferred } \\
\text { visual stimulus }\end{array}$} & \multicolumn{2}{|c|}{ Injection site } & \multicolumn{4}{|c|}{$\begin{array}{l}\text { Distance of retrograde cells from midline } \\
\text { (range in } \mu \mathrm{m} \text {, medial-lateral) }\end{array}$} \\
\hline & & Folium & $\begin{array}{l}\text { Distance from } \\
\text { midline }(\mathrm{mm})\end{array}$ & Rostral & & & Caudal \\
\hline $\begin{array}{l}\text { Translation zone } \\
5 \\
10 \\
12 \text { (left side*) } \\
15 \\
\text { A verage range }\end{array}$ & $\begin{array}{l}\text { feVAd } \\
\text { feVAv } \\
\text { fe45 }{ }^{\circ} \\
\text { feVAd }\end{array}$ & $\begin{array}{l}\text { Ventral IXc, d } \\
\text { Ventral X } \\
\text { Ventral X } \\
\text { D orsal X }\end{array}$ & $\begin{array}{l}- \\
0.6 \\
0.4 \\
0.75\end{array}$ & $\begin{array}{l}456-636 \\
660-920 \\
552-672 \\
482-768 \\
537-749\end{array}$ & $\begin{array}{l}416-760 \\
328-520 \\
336-560 \\
496-816 \\
394-664\end{array}$ & $\begin{array}{l}404-681 \\
352-496 \\
320-560 \\
484-616 \\
390-588\end{array}$ & $\begin{array}{l}520-580 \\
592-812 \\
552-792 \\
520-632 \\
546-704\end{array}$ \\
\hline $\begin{array}{l}\text { R otation zone } \\
6 \\
8 \\
13 \text { (right side*) } \\
16 \\
\text { A verage range }\end{array}$ & $\begin{array}{l}\text { rVA } \\
\text { rVA } \\
\text { r } 45^{\circ} \mathrm{C} \\
\mathrm{rVA}\end{array}$ & $\begin{array}{l}\text { D orsal IXc, d } \\
\text { Ventral IX } \mathrm{X}, \mathrm{d} \\
\text { D orsal IX } \mathrm{X}, \mathrm{d} \\
\text { D orsal X }\end{array}$ & $\begin{array}{l}3.0 \\
2.5 \\
3.1 \\
2.2\end{array}$ & $\begin{array}{l}336-576 \\
208-432 \\
280-376 \\
392-576 \\
304-490\end{array}$ & $\begin{array}{l}352-572 \\
216-384 \\
216-512 \\
236-536 \\
255-501\end{array}$ & $\begin{array}{l}320-504 \\
322-580 \\
242-492 \\
296-528 \\
295-526\end{array}$ & $\begin{array}{l}256-562 \\
304-488 \\
280-484 \\
388-464 \\
309-500\end{array}$ \\
\hline $\begin{array}{l}\text { Translation and ro } \\
12 \text { (right side*) }\end{array}$ & $\begin{array}{l}\text { tation zones } \\
\mathrm{r} 45^{\circ} \mathrm{C} / \mathrm{fe} 45^{\circ} \mathrm{i}\end{array}$ & $\begin{array}{l}\text { Ventral IXc, } \\
\text { d/ dorsal X } \\
\text { Ventral IX c, d }\end{array}$ & $2.3 / 0.0$ & $216-768$ & $164-704$ & 204-584 & $228-482$ \\
\hline $\begin{array}{l}13 \text { (left side*) } \\
\text { A verage range }\end{array}$ & $r 45^{\circ} \mathrm{C} / \mathrm{feV} \mathrm{Av}$ & & 1.6 & $\begin{array}{l}344-936 \\
280-582\end{array}$ & $\begin{array}{l}256-872 \\
210-788\end{array}$ & $\begin{array}{l}168-696 \\
186-640\end{array}$ & $\begin{array}{l}104-672 \\
166-577\end{array}$ \\
\hline $\begin{array}{l}\text { Vermis injections } \\
\quad 17\end{array}$ & $\mathrm{~N}$ on-responsive & $\begin{array}{l}\text { Ventral VIII and } \\
\text { dorsal IX } \mathrm{X}, \mathrm{b}\end{array}$ & 1.6 & $236-432$ & $196-316$ & $164-258$ & $136-348$ \\
\hline $\begin{array}{l}18 \text { - left } 10 \\
\text { - right } 10\end{array}$ & Non-responsive & $\begin{array}{l}\text { D orsal VIII and } \\
\text { ventral VII }\end{array}$ & 0.00 & $\begin{array}{l}690-802 \\
700-1060\end{array}$ & $\begin{array}{l}650-960 \\
640-1100\end{array}$ & $\begin{array}{l}660-990 \\
660-1100\end{array}$ & $\begin{array}{l}720-1130 \\
850-1100\end{array}$ \\
\hline
\end{tabular}

*The side of the injection site.

The visual response types, the folia injected and the distance from the midline of each injection site are indicated. The mediolateral range of retrogradely labeled cells in the IO at four rostrocaudal levels (200-250 $\mu \mathrm{m}$ apart) is also indicated for each case.

The pigeon IO consists of a dorsal (dl) and ventral (vl) lamella, which are joined by the medial column ${ }^{25}$ (mc; see Fig. 4B). A rends and $\mathrm{V}$ oogd ${ }^{1}$ reported that the $\mathrm{VbC}$ receives climbing fiber input largely from the contralateral $\mathrm{mc}$, and to lesser extent the $\mathrm{vl}$ and $\mathrm{dl}$. It was the purpose of this study to investigate the organization of the 10 projections to the physiologically identified translational and rotational zones of the $\mathrm{VbC}$ using the retrograde tracer cholera toxin subunit $B(C T B)$.

\section{EXPERIMENTAL PROCEDURES}

Surgery

The methods reported herein conformed to the guidelines established by the Canadian Council on A nimal Care and were approved by the Biosciences A nimal Care and Policy Committee at the U niversity of A lberta. These guidelines required that efforts were made to ensure that animal discomfort was minimized and that as few animals as possible were used. Experiments were performed on Silver $\mathrm{K}$ ing and $\mathrm{R}$ acing $\mathrm{H}$ omer pigeons (Palmetto Pigeon Plant, Sumpter, N C, U.S.A.) anesthetized with a ketamine $(90 \mathrm{mg} /$ $\mathrm{kg}) /$ xylazine $(15 \mathrm{mg} / \mathrm{kg}$ ) mixture (i.m.); supplemental doses were administered as necessary. The animals were placed in a stereotaxic device with pigeon ear bars and beak adapter so that the orientation of the skull conformed with the atlas of $\mathrm{K}$ arten and Hodos. ${ }^{15}$ Sections of bone and dura were removed to expose the dorsal surface of the flocculus (auricle) of the cerebellum in the area contained by the anterior canal of the vestibular apparatus. On initial penetrations, extracellular recordings were made with glass micropipettes (4 $\mu \mathrm{m}$ tip diameter) filled with $2 \mathrm{M} \mathrm{NaCl}$ which were oriented $45^{\circ}$ to the sagittal plane.

Once CSs of Purkinje cells were isolated, their optic flow field preferences were determined using stimuli described in detail elsewhere. ${ }^{29-32}$ A large (about $90^{\circ} \times 90^{\circ}$ ) stimulus, consisting of a pattern of dark lines and dots on a light background, moving in the central region of each visual field (i.e. along the inter-aural axis), was initially used to identify the CS responses. With this stimulus, translation and rotation cells are easily distinguishable. The former prefer the same direction of motion in this region of both visual fields, whereas the latter prefer the opposite directions in the two visual fields. ${ }^{29,31}$ In some cases, we also used a full-field planetarium projector to present rotational flow fields, ${ }^{30}$ and a full-field "translator" projector to present translational flow fields. ${ }^{32} \mathrm{As}$ in other species, ${ }^{11}$ rotation cells in the pigeon $\mathrm{VbC}$ can be functionally classified into two types: rVA cells prefer rotation about the vertical axis (VA), whereas $r 45^{\circ} \mathrm{C}$ cells prefer rotation about a horizontal axis that is oriented at $45^{\circ}$ contralateral azimuth. ${ }^{30}$ Translation cells can be classified into four functional groups, ${ }^{29,31,32}$ that are most easily described with reference to the location of the fe in the flow field that results in maximal excitation. We have dubbed these four groups feVAd, feVAv, fe $45^{\circ} \mathrm{i}$ and fe $135^{\circ} \mathrm{i}$. The feVAd neurons are excited in response to translational optic flow along the $V A$ with the fe dorsal to the animal's head. The feV A v neurons have the opposite direction preference. They prefer translation along the VA but with the fe ventral to the animal's head. The flow fields that maximally excite feVAd and feV A v cells would result from the pigeon ascending and 

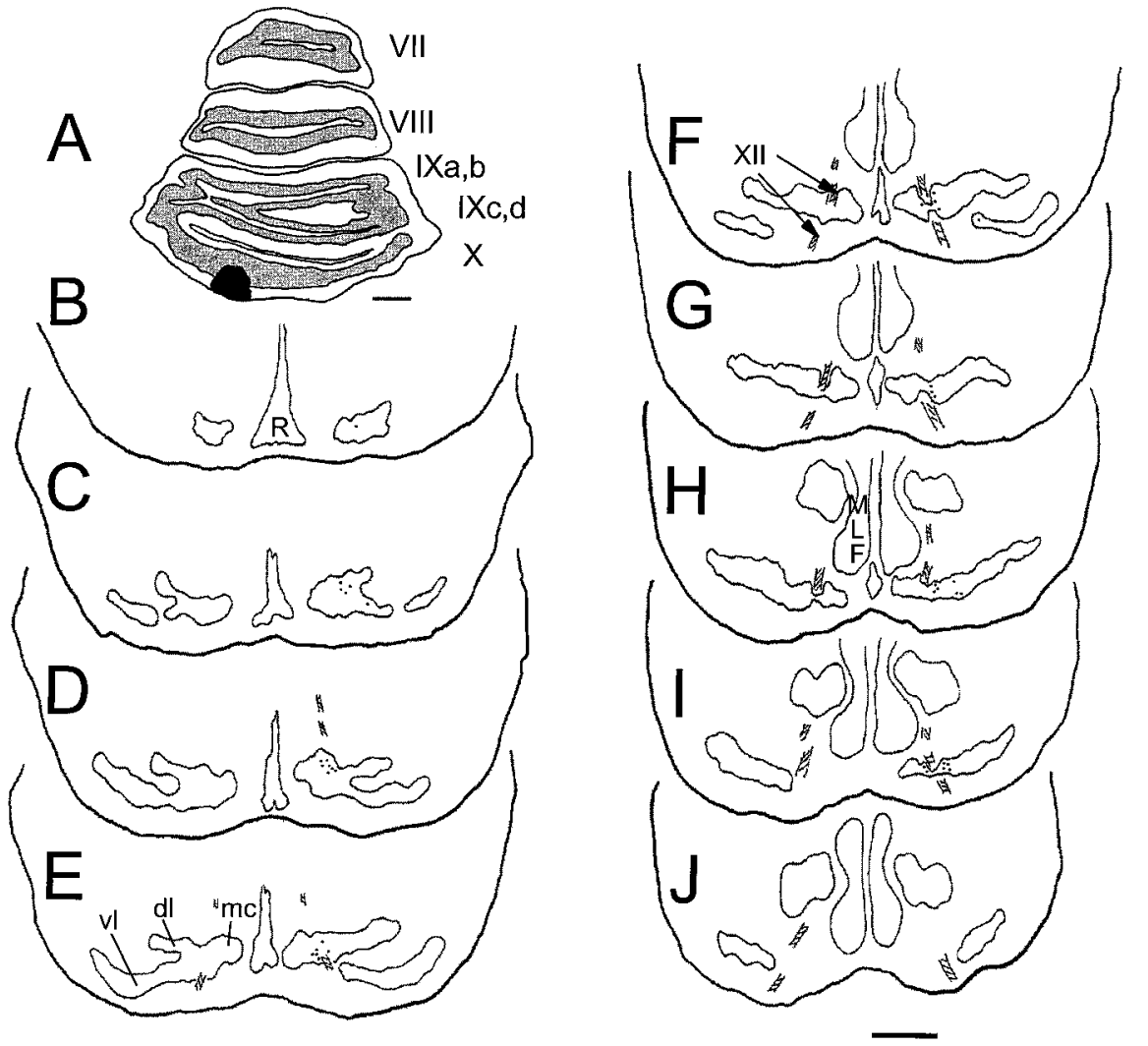

Fig. 1. The distribution of retrogradely labeled cells in the IO following an injection of CTB in the translational zone of the vestibulocerebellum. (A) A camera lucida drawing of a coronal section of the cerebellum from case no. 10 indicating the location of the injection site in the ventral lamella of folium $X$. (B-J) A series of coronal sections (approximately 200-250 $\mu \mathrm{m}$ apart) through the rostrocaudal extent of the 10 , and the location of retrogradely labeled cells. $\mathrm{N}$ ote that most were found in the ventrolateral margin of the $\mathrm{mc}$. Scale bars=1 $\mathrm{mm}(\mathrm{A}), 600 \mu \mathrm{m}(B-J)$.

descending, respectively. The two other types of cells prefer translational optic flow along horizontal axes. The fe $45^{\circ} i$ cells respond best to a translational flow field with an fe at $45^{\circ}$ ipsilateral azimuth. The fe135 $\mathrm{i}$ cells respond best to a translational flow field with an fe at $135^{\circ}$ ipsilateral azimuth.

Once the flow field preference was identified, the recording electrode was removed and replaced with a pipette (tip diameter 16-20 $\mu \mathrm{m}$ ) containing CTB (Sigma, St L ouis, M 0 U.S.A.; $1 \%$ in phosphate-buffered saline, PBS). The solution was pressure injected at the recorded location with a PicoSpritzer II (General Valve Corp.). Subsequent to the CTB injection, biotinylated dextran amine (BDA; M olecular Probes; $10 \%$ in $0.1 \mathrm{M}$ PBS) was iontophoretically injected ( $+3 \mu \mathrm{A}, 1 \mathrm{~s}$ on, $1 \mathrm{~s}$ off) for 2-5 min using micropipettes with tip diameters of $8-12 \mu \mathrm{m}$. Recordings were first made with the BDA injection electrode to ensure that the tip was within the identified zone. Following the BDA injection, the electrode was left undisturbed for an additional 5 min. Injections of BDA were used to help visualize the injection site because the CTB injection sites were very diffuse. Thus, the BDA injection represented the approximate center of the CTB injection site.

Processing for biotinylated dextran amine and cholera toxin subunit $B$

A fter a survival time of three to six days, the animals were given an overdose of sodium pentobarbitol (100 mg/kg) and immediately perfused with saline $(0.9 \%)$ followed by $4 \%$ paraformaldehyde in $0.1 \mathrm{M}$ phosphate buffer (PB). The brains were extracted, postfixed for $2 \mathrm{~h}$ (4\% paraformaldehyde, $20 \%$ sucrose in $0.1 \mathrm{M} \mathrm{PB}$ ), cryoprotected in sucrose overnight ( $20 \%$ in $0.1 \mathrm{M} \mathrm{PB})$ and frozen sectioned in the coronal plane at $40 \mu \mathrm{m}$ thickness. A Iternate sections were collected for CTB and BDA processing. The BDA protocol we used was based on the procedure of $W$ ild $^{26}$ and $V$ eenman et al. ${ }^{24}$ Sections were washed in PBS (at 10-min intervals), incubated in $1 \% \mathrm{H}_{2} \mathrm{O}_{2}$ with $25 \%$ methanol for $20 \mathrm{~min}$, washed in $0.1 \mathrm{M}$ PBS, incubated in ExtrA vidin peroxidase (Sigma; 1:1000) with Triton X-100 (0.4\%) for $1.5 \mathrm{~h}$ at room temperature, washed in PBS, then visualized with diaminobenzidine (DAB). After $10 \mathrm{~min}$ in $0.025 \% \mathrm{DAB}$ in $0.1 \mathrm{M}$ PBS, $0.005 \% \mathrm{H}_{2} \mathrm{O}_{2}$ was added and reacted up to $2 \mathrm{~min}$. The tissue was subsequently washed several times with PBS.

The CTB protocol we used was based on Wild. ${ }^{26}$ The tissue was incubated for $30 \mathrm{~min}$ in $4 \%$ rabbit serum (Sigma; in PBS) with $0.4 \%$ Triton X -100 , followed by goat anti-CTB (List Biological Laboratories; $1: 20,000$ in PBS) with $0.4 \%$ Triton $\mathrm{X}-100$ for $20-24 \mathrm{~h}$ at $4^{\circ} \mathrm{C}$. The tissue was washed with $0.1 \mathrm{M}$ PBS, and then placed in biotinylated rabbit anti-goat (Vector Laboratories; $1: 600$ in PBS) with $0.4 \%$ Triton $\mathrm{X}-100$ for $1 \mathrm{~h}$, washed with PBS, followed by $1.5 \mathrm{~h}$ in ExtrA vidin with $0.4 \%$ Triton $X-100$, rinsed with $P B S$ and then visualized with $D A B$, as with the BDA procedure. In some cases the reaction product was intensified with $0.002 \%$ $\mathrm{CoCl}_{2}$. The tissue was subsequently washed several times with PBS. Sections were then mounted on to gelatin-coated 

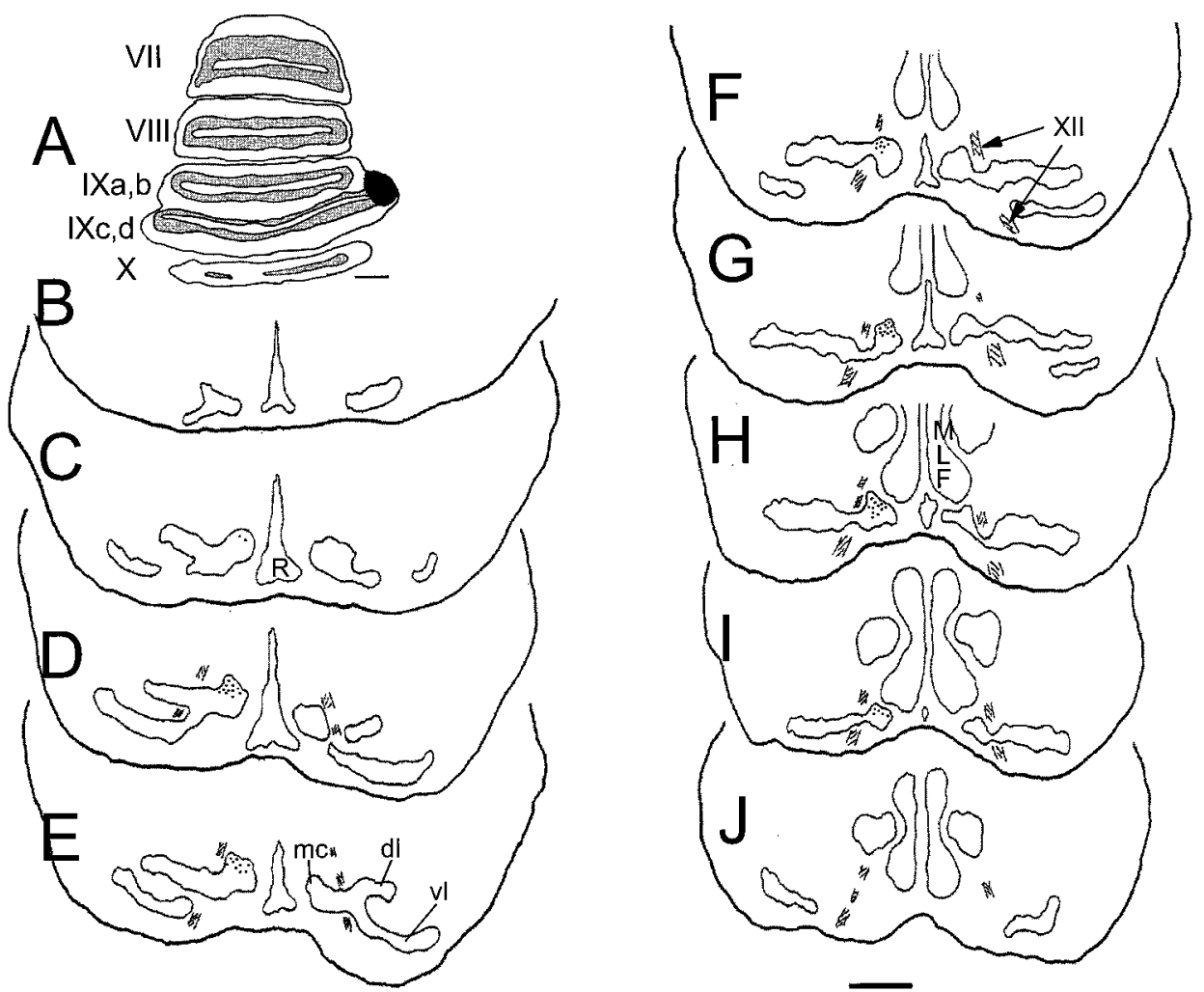

Fig. 2. The distribution of retrogradely labeled cells in the 10 following an injection of CTB in the rotational zone of the vestibulocerebellum. (A) A camera lucida drawing of a coronal section of the cerebellum from case no. 6 indicating the location of the injection site in the pole of folium IX c,d. (B-J) A series of coronal sections (approximately $200-250 \mu \mathrm{m}$ apart) through the rostrocaudal extent of the IO, and the location of retrogradely labeled cells. $\mathrm{N}$ ote that most were found in the dorsomedial margin of the mc. Scale bars=1 mm (A), $600 \mu \mathrm{m}(B-\mathrm{J})$.

slides, dried, counterstained with Giemsa and coverslipped with Permount.

\section{RESULTS}

Injections of CTB were made in 10 pigeons. Two pigeons received bilateral injections, providing 12 cases. In four instances (nos 5, 10, 12 left side, 15) injections were made into the translation zone. Likewise, in four cases (nos 6, 8, 13 right side, 16) injections were made into the rotation zone. In two cases (no. 12 right side, no. 13 left side) injections included both rotation and translation zones (on the same side of the brain). In two other cases (nos 17 and 18), injections were made in the vermis to determine if other areas of the cerebellum receive projections from the mc. BDA injections were performed on all pigeons except for case nos 5, 6 and 8 . Table 1 shows a summary of each individual case, listing the cell response types that were isolated, the folia that were injected and the approximate distance of injection sites from the midline. The table also shows the location (distance from midline) of retrogradely labeled cell bodies in the 10 from four rostrocaudal levels (200-250 $\mu \mathrm{m}$ apart).
In all VbC cases, retrogradely labeled cells were found throughout the rostrocaudal extent of the mc; however, there was a distinct medial-lateral segregation between cells projecting to translation and rotation zones. The cells projecting to translation zones were found in the ventrolateral regions of the $\mathrm{mc}$, whereas cells projecting to rotation zones were concentrated in the dorsomedial regions of the mc. F rom Table 1, the average range of the distance from the midline of retrograde labeled cells, collapsed across all four rostrocaudal levels, was $291 \pm 14.8$ to $504 \pm 16 \mu \mathrm{m}$ for rotation zone injections, and $476 \pm 25$ to $676 \pm 31 \mu \mathrm{m}$ for translation zone injections.

\section{Translation zone injections}

In these four cases, the injection sites were centered 0.4- $0.75 \mathrm{~mm}$ from the midline and found to be located in the ventral uvula or nodulus. In all cases the retrogradely labeled cell bodies were located in the ventrolateral regions of the $\mathrm{mc}$ and were bordered laterally by cranial nerve XII (XII). A few cells were found lateral to XII in the medial areas of the $\mathrm{dl}$ and $v l$. Figure 1 shows a series of coronal section drawings from case no. 10, illustrating the injection site 

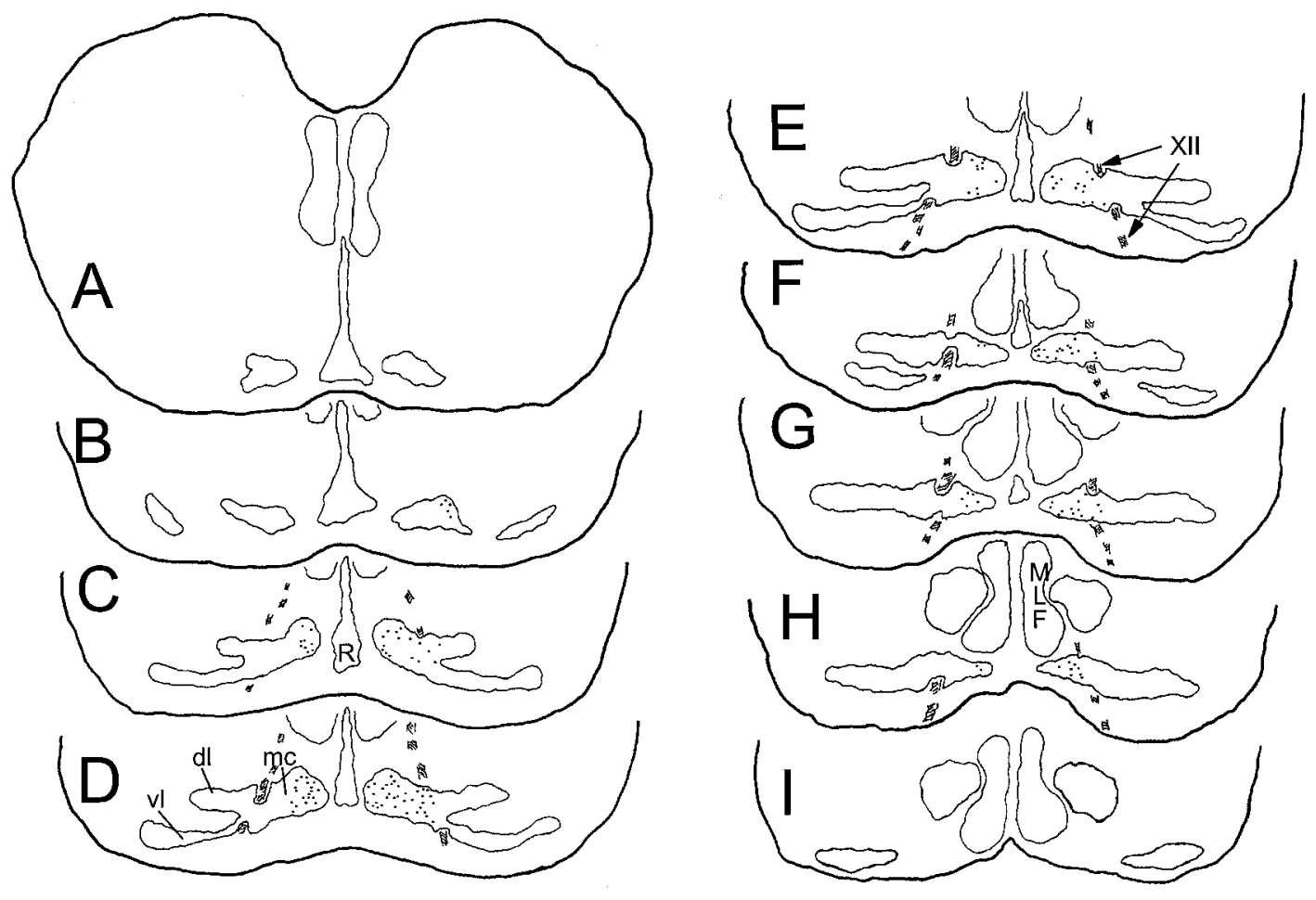

Fig. 3. Retrogradely labeled cells in the 10 following injections of CTB into the rotational and translational zones of the $\mathrm{VbC}$. This series of coronal sections through the rostrocaudal extent of the IO is from case no. 13. The retrogradely labeled cells in the left 10 were labeled from an injection in the rotation zone of the right $\mathrm{VbC}$. The retrogradely labeled cells in the right IO were labeled from an injection that included both the translation and rotation zones of the left $\mathrm{VbC}$. Scale bar $=600 \mu \mathrm{m}$.

(Fig. $1 A$ ) and distribution of retrogradely labeled cells in the IO (Fig. 1B-J). Photomicrographs of the retrogradely labeled cells in the ventrolateral margin of the $\mathrm{mc}$ resulting from translation zone injections are shown in $\mathrm{Fig.} 4 \mathrm{~A}$ and $\mathrm{C}$.

\section{Rotation zone injections}

These injection sites were centered 2.2-3.1 mm from the midline. In all cases the retrogradely labeled cells were concentrated in the dorsomedial regions of the $\mathrm{mc}$, including the area described as the dorsal cap by $A$ rends and $\mathrm{Voogd}^{1}$ (see Fig. 2D-G). Figure 2 show a series of coronal section drawings illustrating the characteristic distribution of retrogradely labeled cells in the dorsomedial mc (see IO on the left side of the brain in Fig. 3). Photomicrographs of the retrogradely labeled cells resulting from rotation zone injections are shown in $\mathrm{Fig} .4 \mathrm{~B}$ and $\mathrm{D}$. N ote the distinction between the locations of cells labeled from translation zone injections ( $\mathrm{Fig} .4 \mathrm{~A}, \mathrm{C}$ ) and rotation zone injections ( $\mathrm{Fig} .4 \mathrm{~B}, \mathrm{D}$ ).

I njections including both translation and rotation zones

In case no. 12 the injection into the translation zone of the left $\mathrm{VbC}$ extended across the midline to include the translation zone on the right side. $\mathrm{A}$ subsequent injection was made laterally in the rotation zone of the right $\mathrm{V} \mathrm{bC}$. In case no. 13 (left side), the injection site was centered $1.6 \mathrm{~mm}$ from the midline but spread laterally to include the rotation zone. At this injection site, $r 45^{\circ} \mathrm{C}$ cells and feV Av responses were recorded $150 \mu \mathrm{m}$ apart. Thus, in these two cases, the retrogradely labeled cells in the 10 represent projections to both translation and rotation zones. In both cases retrogradely labeled cells were found distributed throughout the mediolateral extent of the $\mathrm{mc}$, and a few cells were found lateral to XII, in the medial areas of the $\mathrm{dl}$ and $\mathrm{vl}$. F igure 3 shows a series of coronal section drawings illustrating the distribution of retrogradely labeled cell bodies throughout the $\mathrm{mc}$ from case no. 13 (left side; see 10 on the right side of the brain in $\mathrm{Fig}$. 3). The average range of the distance from midline of the retrogradely labeled cells from both cases was $210 \pm 25$ to $714 \pm 52 \mu \mathrm{m}$. This range encompassed the measurements derived from cases where the injection was confined to either the translational or rotational zone.

\section{Vermal injections}

Vermal injections were conducted to determine if other areas of the cerebellum received projections from the mc. The vermal Purkinje cells at the 

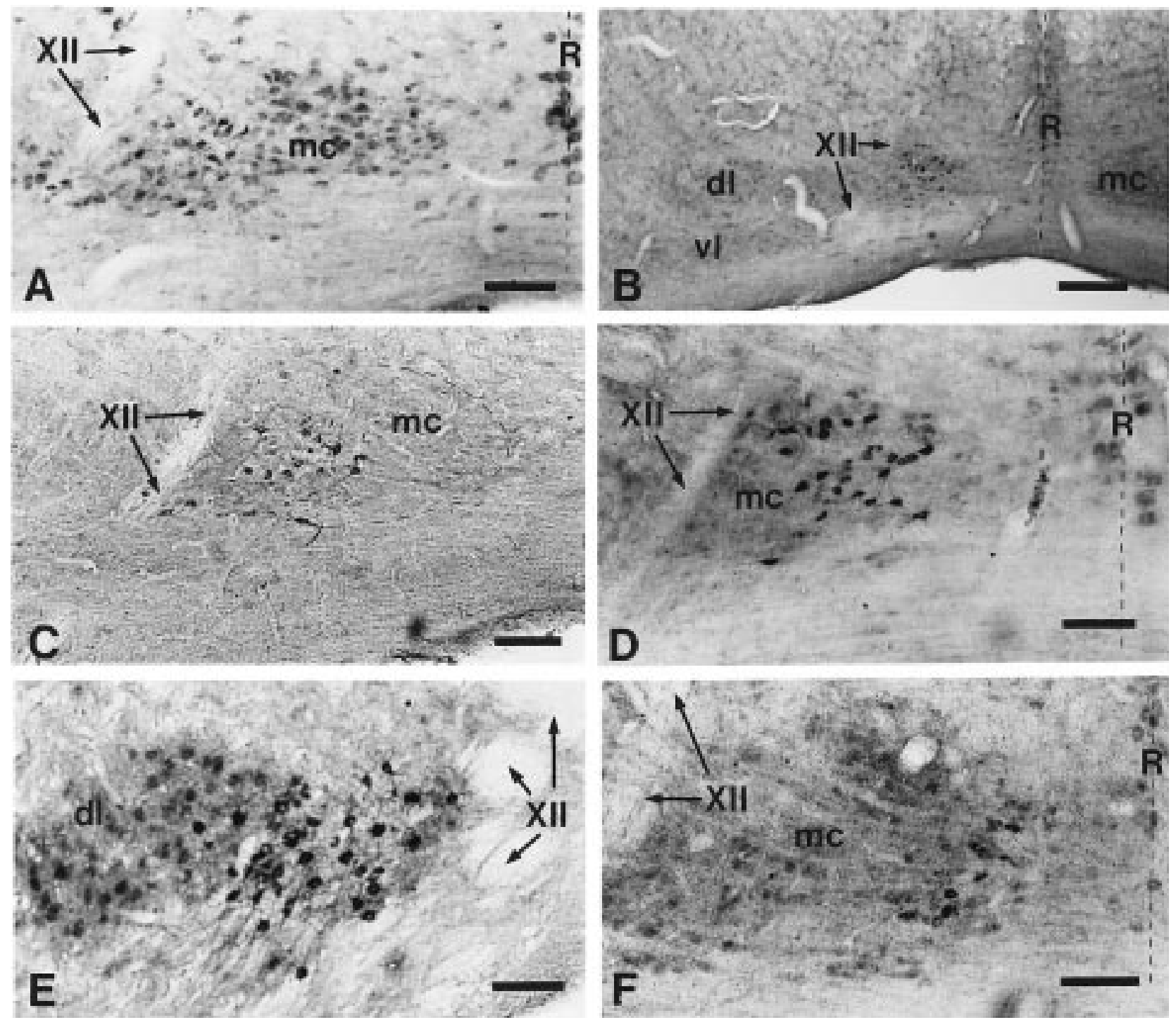

Fig. 4. R etrogradely labeled cells in the IO following injections of CTB in the cerebellum. B clearly shows the three subdivisions of the IO: the $\mathrm{dl}, \mathrm{vl}$ and $\mathrm{mc}$. The $\mathrm{mc}$ is bordered laterally by cranial nerve XII (XII). The dashed vertical lines represent the midline. The midline in $C$ is not within the area of the photograph. $\mathrm{A}$ and $\mathrm{C}$ are photomicrographs showing retrogradely labeled cells in the ventrolateral $\mathrm{mc}$ resulting from an injection in the translation zone (case no. 15). In A, approximately 10 cells were labeled in the lateral half of the mc. The cell bodies are difficult to identify because the D A B reaction was not intensified with $\mathrm{CoCl}_{2}$ and the section was counterstained with $\mathrm{G}$ iemsa. In C, the retrogradely labeled cells are more easily seen in a section that was not counterstained. The dashed line in $C$ indicates the extent of the $\mathrm{mc}$. $B$ and $\mathrm{D}$ show the retrogradely labeled cells from injections in the rotation zones of the $\mathrm{VbC}$ (case no. 16). N ote that the cells were located in the dorsomedial margin of the $\mathrm{mc}$. E shows retrogradely labeled cells in an area in the medial margin of the dl, lateral to XII, from the injection into the medial vermis (case no. 18). The dark cells in the center of the photograph are CTB labeled, whereas the lighter cells to the left are counterstained with Giemsa but not CTB labeled. F shows a ventromedial strip of retrogradely labeled cells in the $\mathrm{mc}$ from an injection into the lateral vermis (case no. 17). Scale bars $=100 \mu \mathrm{m}$ $(A, C-F), 250 \mu m(B)$.

injection sites exhibited no modulation in response to visual stimuli. In case no. 17 the injection was centered $1.6 \mathrm{~mm}$ from the midline in the lateral-most aspect of the vermis (see Fig. 5A). Retrogradely labeled cells were found in a small strip in the ventromedial $\mathrm{mc}$ and some were found in the vl. Figure 5 is a series of coronal section drawings showing the distribution of retrogradely labeled cells in the ventromedial $\mathrm{mc}$ and vl. A photomicrograph of retrogradely labeled cells in the ventromedial $\mathrm{mc}$ from this case is shown in $\mathrm{Fig}$. $4 \mathrm{~F}$.

In case no. 18, the injection was centered near the midline (see Fig. 6A) and resulted in bilateral retrograde labeling in the 10 . The medial aspect of the $\mathrm{dl}$, 


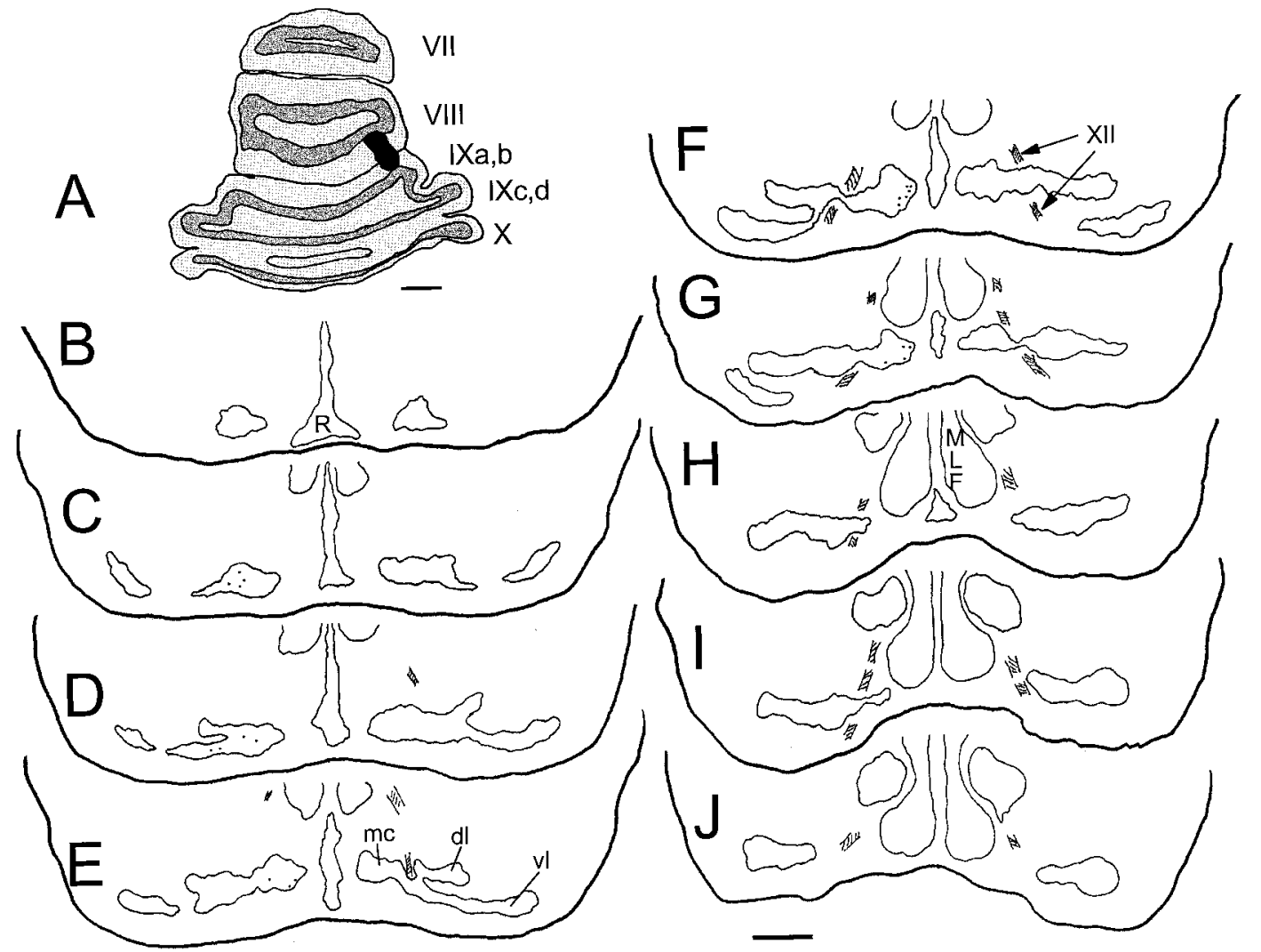

Fig. 5. The distribution of retrogradely labeled cells in the IO following an injection of CTB in the lateral vermis (case no. 17). (A) A camera lucida drawing of a coronal section of the cerebellum indicating the location of the injection site in folia VIII and IX a,b. (B-J) A series of coronal sections (approximately $200-250 \mu \mathrm{m}$ apart) through the rostrocaudal extent of the IO, and the location of retrogradely labeled cells. $\mathrm{N}$ ote that a strip of cells was found in the ventromedial margin of the $\mathrm{mc}$, and a few were found in the vl. Scale bars $=1 \mathrm{~mm}(\mathrm{~A}), 600 \mu \mathrm{m}(\mathrm{B}-\mathrm{J})$.

lateral to XII, was extensively labeled on both sides, and a few cells were found in the medial vl. No retrogradely labeled cells were found in the $\mathrm{mc}$. Figure 6 shows the distribution of retrogradely labeled cells in the dl. A photomicrograph of the retrogradely labeled cells in the $\mathrm{dl}$, found lateral to $X I I$, is shown in Fig. $4 \mathrm{E}$.

\section{DISCUSSION}

In this report we have shown that zones in the pigeon $\mathrm{VbC}$, containing Purkinje cells responsive to either translational or rotational optic flow, receive differential climbing fiber inputs from the IO. Injections of CTB in the translation zone retrogradely labeled cells in the ventrolateral mc. In contrast, injections of CTB in the rotation zone retrogradely labeled cells in the dorsomedial mc. Thus, just two synapses from the retina, this specific visual pathway is already segregated into channels specifying translational and rotational optic flow.

It is very likely that the rotation and translation areas of the 10 are segregated further. In mammals, the flocculus and the nodulus contain cells sensitive to rotational optic flow, ${ }^{11,14,17}$ but the different sub- types are organized in parasagittal zones that receive differential climbing fiber input. Cerebellar zones containing rVA cells receive input from the caudal dorsal cap, whereas $r 45^{\circ} \mathrm{C}$ cells receive input from the rostral dorsal cap and ventrolateral outgrowth. ${ }^{2,16,23}$ $\mathrm{N}$ onetheless, in the present study, we found no appreciable differences in the location of retrograde labeling in the 10 following injections at locations containing rVA vs $r 45^{\circ} \mathrm{C}$ cells. Likewise, we found no obvious differences in the locations of retrogradely labeled cells following injections in areas of the translation zone at locations containing different response types. However, our injections were not small and likely included any subzones contained within the translation and rotation zones.

\section{Comparison with previous studies}

A rends and $V_{0 o g d}{ }^{1}$ divided the pigeon cerebellum into five parasagittal zones (zones A-C, E and F) based on climbing fiber projections. The most medial zone, zone $A$, received input from the dl, which was confirmed in the present study (case no. 18). The anterior and posterior aspects of zone $B$ received 


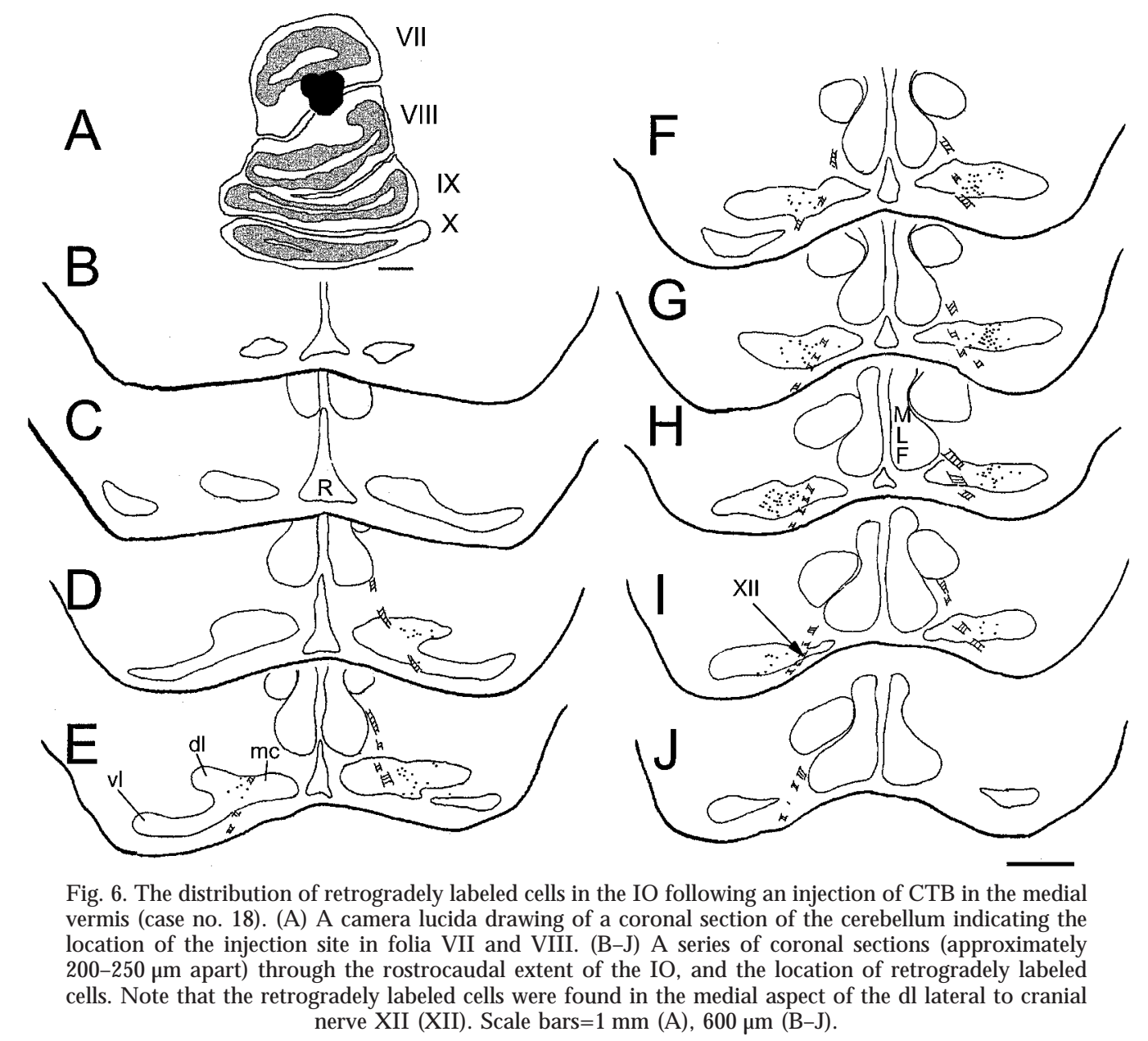

input from the caudal $\mathrm{vl}$ and ventromedial $\mathrm{mc}$, respectively. Zone $\mathrm{C}$ received input from the $\mathrm{vl}$. Zone $\mathrm{E}$ received input from the ventral $\mathrm{mc}$, which was confirmed in the present study (case no. 17). F inally, the most lateral zone, zone $F$, consisted only of the lateral half of the $\mathrm{VbC}$ (flocculus) and received input from the dorsal $\mathrm{mc}$. These five zones transcended all folia, including folia IXc, d and X of the $\mathrm{VbC}$, with the exception that zone $A$ in the ventral uvula and nodulus received input from the mc. However, A rends and $V$ oogd ${ }^{1}$ did state that the zonal organization of climbing fiber inputs to the $\mathrm{VbC}$ was not completely determined in their study.

Our data from the present study suggest that the $\mathrm{VbC}$ does not contain the same zonal organization as the vermis (this is also the case in mammals, where the zones of the flocculus and nodulus do not correspond to those of other parts of the cerebellum ${ }^{13}$ ). $L$ ike A rends and $V$ oogd, ${ }^{1}$ we found that both medial and lateral aspects of the $\mathrm{VbC}$ receive input from the $\mathrm{mc}$, but we have also shown that this projection is subdivided further. We could not confirm the presence of a zone $C$ (which is rather wide in the drawings of $A$ rends and $V_{\text {oogd }}{ }^{1}$ ) in the nodulus or ventral uvula, as retrogradely labeled cells in the $\mathrm{vl}$ were rarely observed.

\section{Comparative considerations}

The fundamental difference between the $\mathrm{VbC}$ in pigeons and mammals is very clear from electrophysiological studies. In pigeons, the flocculus contains cells responsive to rotational optic flow, whereas in the nodulus and ventral uvula cells are responsive to translational optic flow. ${ }^{29-32}$ In rabbits, there are zones in the ventral uvula, nodulus and flocculus that contain cells responsive to rotational optic flow ${ }^{11,14,17,28}$ but, as yet, Purkinje cells responsive to translational optic flow have not been identified in the cerebellum of species other than the pigeon (it is possible that cells responsive to translational optic flow are peculiar to flying animals, but there are no data available from flying mammals. L ikewise, it is possible that cells responsive to translational optic flow are peculiar to head-bobbing birds, but there are no data available from other bird species). G iven these findings, it is not surprising that, in rabbits, the ventral uvula, nodulus and flocculus 
receive input from the same areas of the 10 , namely the dorsal cap and ventrolateral outgrowth. 2,16,23 In fact, Takeda and $M$ aekawa ${ }^{21,22}$ have shown that individual 10 neurons in rabbits project to the uvula/ nodulus and the flocculus. F rom the present study we conclude that the dorsomedial $\mathrm{mc}$ of pigeons is functionally equivalent to the dorsal cap and ventrolateral outgrowth of mammals, because these structures provide input to rotation cells.

The nodulus/uvula of rabbits also receives a large climbing fiber input from the beta subnucleus of the 10 to the most medial zone. ${ }^{2,16,23}$ Barmack et al. ${ }^{3,4,5}$ have shown that many neurons in this zone and the beta subnucleus respond to static head tilt, thus demonstrating an input originating in the otolith organs. Although not self-translation per se, the medial zone of the nodulus/uvula and the beta subnucleus in rabbits receive inputs related to linear acceleration during self-motion, as does the medial $\mathrm{VbC}$ in pigeons. For these reasons, we suggest that the beta subnucleus in mammals might be functionally similar to the ventrolateral $\mathrm{mc}$ in pigeons.

\section{CONCLUSIONS}

The vestibulocerebellum in pigeons can be divided into two parasagittal zones that contain Purkinje cells whose CS activity is maximally modulated by either translational or rotational optic flow stimuli. The lateral zone of the V bC contains rotation cells and receives climbing fiber input from the dorsomedial region of the $\mathrm{mc}$ of the $\mathrm{I} 0$. The medial zone of the $\mathrm{VbC}$ contains tranlsation cells and receives climbing fiber input from the ventrolateral region of the $\mathrm{mc}$ of the 10 .

\section{REFERENCES}

1. A rends J. J. A . and Voogd J. (1989) Topographic aspects of the olivocerebellar system in the pigeon. Expl Brain R es., Suppl. 17, 52-57.

2. Balaban C. D. and Henry R. T. (1984) Olivo-vestibular and cerebello-vestibular connections in albino rabbits. N euroscience 12, 129-149.

3. Barmack N. H., Fagerson M., Fredette B. J., M ugnaini E. and Shojaku H. (1993) A ctivity of neurons in the beta nucleus of the inferior olive of the rabbit evoked by natural vestibular stimulation. Expl Brain Res. 94, $203-215$.

4. Barmack N. H. and Shojaku H. (1992) R epresentation of a postural coordinate system in the nodulus of the rabbit cerebellum by vestibular climbing fibre signals. In V estibular Control of E ye, $\mathrm{H}$ ead and B ody M ovements (eds Shimazu H. and Shimoda Y.), pp. 331-338. Japan Scientific Societies Press, Tokyo.

5. Barmack N. H. and Shojaku H . (1995) Vestibular and visual climbing fibre signals evoked in the uvula-nodulus of the rabbit cerebellum by natural stimulation. J. N europhysiol. 74, 2573-2589.

6. Brecha N., Karten H.J. and Hunt S. P. (1980) Projections of the nucleus of basal optic root in the pigeon: an autoradiographic and horseradish peroxidase study. J . comp. N eurol. 189, 615-670.

7. Clarke P. G. H. (1977) Some visual and other connections to the cerebellum of the pigeon. J. comp. N eurol. 174, 535-552.

8. Gamlin P. D. R. and Cohen D. H. (1988) Projections of the retinorecipient pretectal nuclei in the pigeon (Columba livia). J. comp. N eurol. 269, 18-46.

9. Gibson J. . . (1954) The visual perception of objective motion and subjective movement. P sychol. R ev. 61, 304-314.

10. Gibson J. J. (1958) Visually controlled locomotion and visual orientation in animals. Br. J. P sychol. 49, 182-194.

11. Graf W., Simpson J. and Leonard C. S. (1988) Spatial organization of visual messages of the rabbit's cerebellar flocculus. II. Complex and simple spike responses of Purkinje cells. J. N europhysiol. 60, 2091-2121.

12. Grasse K. L. and Cynader M. S. (1990) The accessory optic system in frontal-eyed animals. In Vision and Visual Dysfunction, The Neuronal Basis of V isual Function (ed. L eventhal A.), Vol. 4, pp. 111-139. M acM illan, N ew Y ork.

13. Groenewegen H. J., Voogd J. and Freedman S. L. (1979) The parasagittal zonation within the olivocerebellar projection. II. Climbing fibre distribution in the intermediate and hemispheric parts of cat cerebellum. J . comp. N eurol. $183,551-602$.

14. K ano M., K ano M.-S., K usonoki M . and M aekawa K. (1990) N ature of optokinetic response and zonal organization of climbing fibre afferents in the vestibulocerebellum of the pigmented rabbit. II. The nodulus. Expl Brain Res. 80, 238-251.

15. Karten H.J. and Hodos W. (1967) A Stereotaxic Atlas of the Brain of the Pigeon (Columba livia). Johns Hopkins Press, Baltimore, M D.

16. K atayama S. and N isimaru N . (1988) Parasagittal zonal pattern of olivo-nodular projections in rabbit cerebellum. N eurosci. Res. 5, 424-438.

17. K usonoki M., K ano M., K ano M.-S. and M aekawa K. (1990) N ature of optokinetic response and zonal organization of climbing fibre afferents in the vestibulocerebellum of the pigmented rabbit. I. The flocculus. Expl Brain Res. 80, $225-237$.

18. Schwarz I. E. and Schwarz D. W. F. (1983) The primary vestibular projection to the cerebellar cortex in the pigeon (Columba livia). J. comp. N eurol. 216, 438-444.

19. Simpson J. I. (1984) The accessory optic system. A. R ev. N eurosci. 7, 13-41.

20. Simpson J. I., L eonard C. S. and Soodak R. E. (1988) The accessory optic system of rabbit. II. Spatial organization of direction selectivity. J. N europhysiol. 60, 2055-2072.

21. Takeda T. and M aekawa K. (1989) Olivary branching projections to the flocculus, nodulus and uvula in the rabbit. I. A n electrophysiological study. Expl Brain Res. 74, 47-62.

22. Takeda T. and M aekawa K. (1989) Olivary branching projections to the flocculus, nodulus and uvula in the rabbit. II . R etrograde double labelling study with fluorescent dyes. Expl Brain Res. 76, 323-332.

23. Tan J., Gerrits N. M., N anhoe R. S., Simpson J. I. and Voogd J. (1995) Zonal organization of the climbing fibre projection to the flocculus and nodulus of the rabbit: a combined axonal tracing and acetylcholinesterase histochemical study. J . comp. N eurol. 356, 23-50. 
24. Veenman C. L., R einer A . and H onig M . G . (1992) Biotinylated dextran amine as an anterograde tracer for single- and double-labelling studies. J. N eurosci. M eth. 41, 239-254.

25. Vogt-N ilson L. (1954) The inferior olive in birds. A comparative morphological study. J. comp. Neurol. 101, 447-481.

26. Wild J. M. (1993) Descending projections of the songbird nucleus robustus archistrialis. J. comp. Neurol. 338, 225-241.

27. Wilson V. J. and M elvill J ones G . (1979) M ammalian Vestibular P hysiology. Plenum, N ew Y ork.

28. Wylie D. R., D e Zeeuw C. I. and Simpson J. I. (1995) Temporal relations of the complex spike activity of Purkinje cell pairs in the vestibulocerebellum of rabbits. J. Neurosci. 15, 2875-2887.

29. Wylie D. R . and Frost B. J. (1991) Purkinje cells in the vestibulocerebellum of the pigeon respond best to either rotational or translational visual flow. Expl Brain Res. 86, 229-232.

30. Wylie D. R . and F rost B. J. (1993) R esponses of pigeon vestibulocerebellar neurons to optokinetic stimulation. II. The 3-dimensional reference frame of rotation neurons in the flocculus. J. N europhysiol. 70, 2647-2659.

31. Wylie D. R., K ripalani T. K . and F rost B. J. (1993) R esponses of pigeon vestibulocerebellar neurons to optokinetic stimulation. I. Functional organization of neurons discriminating between translational and rotational visual flow. J. Neurophysiol. 70, 2632-2646.

32. Wylie D. R. W., L au K., G lover R. G . and F rost B. J. (1998) O ptic flow: a common reference frame for self-translation and self-rotation. Soc. N eurosci. A bstr. 23, 1821.

33. Wylie D. R. W., Linkenhoker B. and Lau K. L. (1998) Projections of the nucleus of the basal optic root in pigeons (Columba livia) revealed with biotinylated dextran amine. J. comp. N eurol. 384, 517-536. 